\title{
Intraspecific Variation in the Wing Shape of the Mango Leafhopper, Idioscopus Clypealis, among Orchards in the Philippines
}

\author{
Mark Ronald S. Manseguiao ${ }^{1 *}$, Cesar G. Demayo ${ }^{2}$ \\ ${ }^{1}$ Institute of Education, Davao del Norte State College, Panabo City, Philippines. \\ 2 Department of Biological Sciences, College of Science and Mathematics, Mindanao State University - Iligan \\ Institute of Technology, Iligan City, Philippines. \\ * Corresponding author. Tel.: +63 84 6284301; email: mark.manseguiao@gmail.com \\ Manuscript submitted July 12, 2018; accepted December 1, 2018. \\ doi: 10.17706/ijbbb.2019.9.1.27-34
}

\begin{abstract}
Plants have differential expression of genes despite being propagated through cloning as in the case of mango. This study aimed to determine the effect of intraspecific variation in the host mangoes to the wing shape of the mango leafhopper, Idioscopus clypealis. Leafhopper populations were collected from four different orchards from individual trees. Wings were dissected, imaged and analyzed using multivariate analysis of variance, thin plate spline analysis and relative warp analysis. Results showed significant variation across all sampled trees in each geographic location regardless of farm management methods in the wing shape of the leafhopper. This variation is observed between genders and between trees in an orchard. Results also show that there is intraspecific variation in each host tree even in unsprayed populations and organic pesticide use. High adaptability to host defense and pesticides evidenced by wing variation may be key to persistence in this high value crop despite natural and synthetic control measures.
\end{abstract}

Key words: Mango leafhopper, geometric morphometrics, thin plate splines, relative warp analysis.

\section{Introduction}

Plants are similar to animals in that they have defense systems despite being immobile [1]-[3]. Aside from structural defense mechanisms, plants produce metabolites that aid in the defense against herbivory and other pathogenic attacks [4]-[6]. Attack on one plant can also be communicated to other plants [7], [8]. Plant defense can also be variable which may have an effect on the effectivity of attack [9]-[12]. The intraspecific variability in plants have a genetic basis in the regulation of metabolites produced [13]-[15].

The variable plant response may induce a similar variable response in pests. According to the geographic mosaic of coevolution, the interaction of the plant and pest may induce a reciprocal selection process [16], [17]. This selection process induces changes in the participants in an arms race to adapt and survive [18]-[20].

This study purposes to examine the effect of intraspecific variation in mango trees produces a variable phenotype on the mango leafhopper, Idioscopus clypealis. This allows us to identify the variability that is observed in orchard. The variable plant defense of the tree might induce wing shape changes that might allow it to better adapt and survive in each unique host.

\section{Materials and Methods}




\subsection{Sample Collection}

Mango orchards were visited in 4 geographical locations in the Visayas and Mindanao (see Table 1). A clear plastic bag with approximately $2 \mathrm{ml}$ of ethanol was used to capture the mango leafhoppers on the leaves and branches by encasing it quickly with the bag then removing it slowly. Only leafhoppers in the lower fringes of the tree was collected. The leafhopper becomes entrapped by the liquid. The specimen is then transferred onto a small plastic container with ethanol as preservative.

Table 1. Location of Sampling Sites

\begin{tabular}{lcccc}
\hline \hline \multicolumn{1}{c}{ Location } & No. of Tree & Pesticide use & Latitude & Longitude \\
\hline Sibunag, Guimaras & 3 & Unsprayed & $10^{\circ} 29^{\prime} 04.8^{\prime \prime} \mathrm{N}$ & $122^{\circ} 38^{\prime} 49.5^{\prime \prime} \mathrm{E}$ \\
Guimaras Wonders Farm, Guimaras Is. & 8 & Organic pesticide & $10^{\circ} 37^{\prime} 50.8^{\prime \prime} \mathrm{N}$ & $122^{\circ} 36^{\prime} 42.2^{\prime \prime} \mathrm{E}$ \\
Lacida Farm, Brgy. Buru-un, Iligan City & 3 & Chemical pesticide & $8^{\circ} 10^{\prime} 54.6^{\prime \prime} \mathrm{N}$ & $124^{\circ} 10^{\prime} 17.7^{\prime \prime} \mathrm{E}$ \\
Brgy. McClain, Buenavista, Guimaras & 4 & Chemical pesticide & $10^{\circ} 42^{\prime} 09.3^{\prime \prime} \mathrm{N}$ & $122^{\circ} 39^{\prime} 54.1^{\prime \prime} \mathrm{E}$ \\
\hline \hline
\end{tabular}

\subsection{Materials and Methods}

The specimens were identified using the guide by [21]. Male and female specimens were separated (see Fig. 1). The forewings were dissected by teasing the wing from the thorax using needles separating left and right forewings. Each wing was then mounted onto a glass slide with a small drop of glycerin.
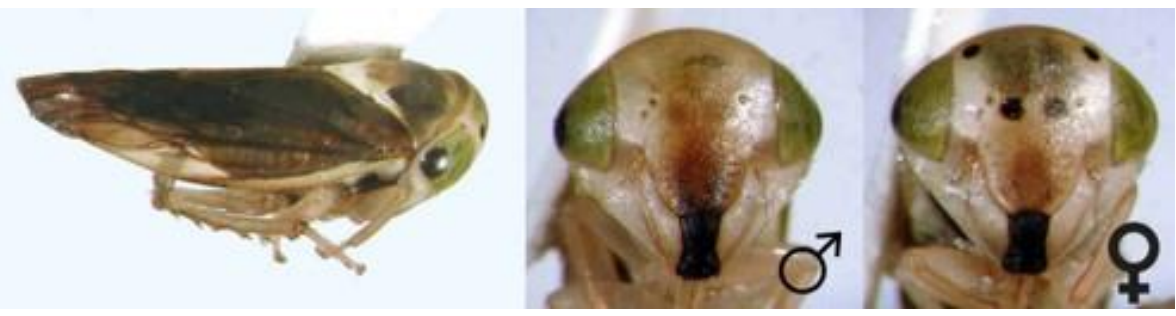

Fig. 1. Image guide of Idioscopus clypealis and sex characterization of male and female [22].

\subsection{Image Acquisition and Landmarking}

Images of each wing was acquired using a digital camera attached to a stereomicroscope. Images were then replicated three times. Eighteen (18) landmarks were selected using the venation of the wing (see Fig 2). These landmarks were selected to indicate vein junctions in the wing. The tpsUtility program v1.44 software [23] was used to create an image directory where landmarks can be superimposed using tpsDig v2.12 [24].

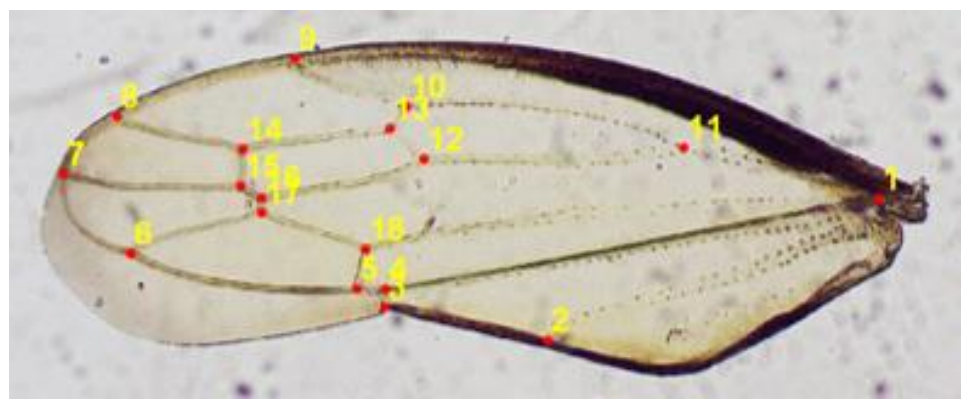

Fig. 2. Landmarks used on the wing of Idioscopus clypealis.

\subsection{Statistical Analysis}


Raw landmark coordinates were extracted and Procrustes-transformed using PaST v2.15 [25] to standardize the dataset [26]. Procrustes transformation removes variation of the landmarks due to digitizing location, orientation and scale projecting the image onto a common coordinate system [27]. Thin plate splines were then generated to observe the mean shape of the wing within populations.

Relative warp analysis was done to determine within group variability [26]-[28]. Rohlf [29] posits that this method can identify the major trends in variation among specimens within a sample as deformations of shape by creating a space where landmark coordinates are superimposed, create a standardized shape and compared to the samples. Relative warp program v1.46 [30] was used to provide the analysis and visualization of the landmarks. Analysis of variance of the relative warps was computed to verify significant difference in the populations visualized through canonical variate analysis. Distribution of the populations will be visualized using histograms and boxplots generated through PaST v2.15 [25].

\section{Results and Discussion}

The significance of relative warp scores of the samples trees in each location was tested using multivariate analysis of variance (see Table 2). Across all locations there were significant differences in the sampled populations. Significant difference is observed in the male and female wings. The left and right wings also show significant difference.

Table 2. Multivariate Analysis of Relative Warp Scores across Orchards in the Philippines

\begin{tabular}{lcccl}
\hline \hline \multicolumn{1}{c}{ Source of Variation } & Wilks $\lambda$ & $\mathrm{F}$ & $\mathrm{p}($ same $)$ & Remarks \\
\hline Sibunag, Guimaras Is. & & & & \\
$\quad$ Left Wing Female & 0.8037 & 2.951 & $2.873 \times 10^{-13}$ & Significant \\
Left Wing Male & 0.7697 & 3.22 & $1.909 \times 10^{-15}$ & Significant \\
Right Wing Female & 0.7725 & 3.29 & $4.321 \times 10^{-16}$ & Significant \\
Right Wing Male & 0.7262 & 3.996 & $2.75 \times 10^{-22}$ & Significant \\
Guimaras Wonders Farm, Guimaras Is. & & & & \\
Left Wing Female & 0.02068 & 3.605 & $1.895 \times 10^{-44}$ & Significant \\
Left Wing Male & 0.1209 & 2.638 & $8.248 \times 10^{-28}$ & Significant \\
Right Wing Female & 0.03994 & 3.061 & $2.922 \times 10^{-34}$ & Significant \\
Right Wing Male & 0.08569 & 3.111 & $1.578 \times 10^{-38}$ & Significant \\
Lacida Farm, Brgy. Buruun, Iligan City. & & & & \\
Left Wing Female & 0.6013 & 2.434 & $3.732 \times 10^{-08}$ & Significant \\
Left Wing Male & 0.6371 & 1.983 & $2.873 \times 10^{-05}$ & Significant \\
Right Wing Female & 0.5605 & 2.853 & $5.152 \times 10^{-11}$ & Significant \\
Right Wing Male & 0.5489 & 2.875 & $4.243 \times 10^{-11}$ & Significant \\
McClain, Buenavista, Guimaras & & & & \\
Left Wing Female & 0.003332 & 4.515 & $5.626 \times 10^{-11}$ & Significant \\
Left Wing Male & 0.1025 & 3.779 & $3.782 \times 10^{-19}$ & Significant \\
Right Wing Female & 0.07816 & 3.959 & $6.49 \times 10^{-11}$ & Significant \\
Right Wing Male & 0.156 & $7.423 \times 10^{-22}$ & Significant \\
\hline \hline
\end{tabular}

This asymmetry in the wings is observed in the generated thin plate splines. Thin plate splines were computed to show contraction and expansion between landmark points in the wings of both sexes and gender (Fig. 3-6). Results show that there is asymmetry in the wings within trees where the contraction and expansion points are not congruent to other tree populations within an orchard. Male and female thin plate splines also do not correspond in symmetry between points. The same is also observed between the left 
and right wings also show non-correspondence of points. The right female wings of the Sibunag population may seem to have congruency of expansion and contraction points but the degree to which landmark points expand and contract seem to affect the results of the MANOVA test.

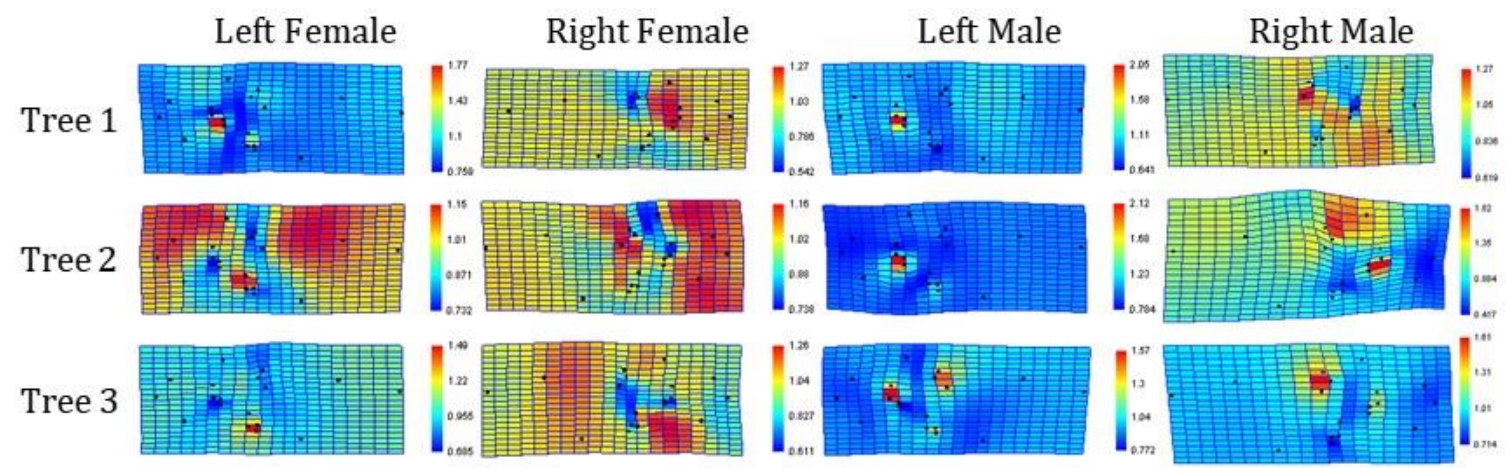

Fig. 3. Thin plate splines of wings between sampled trees in Sibunag, Guimaras Is.

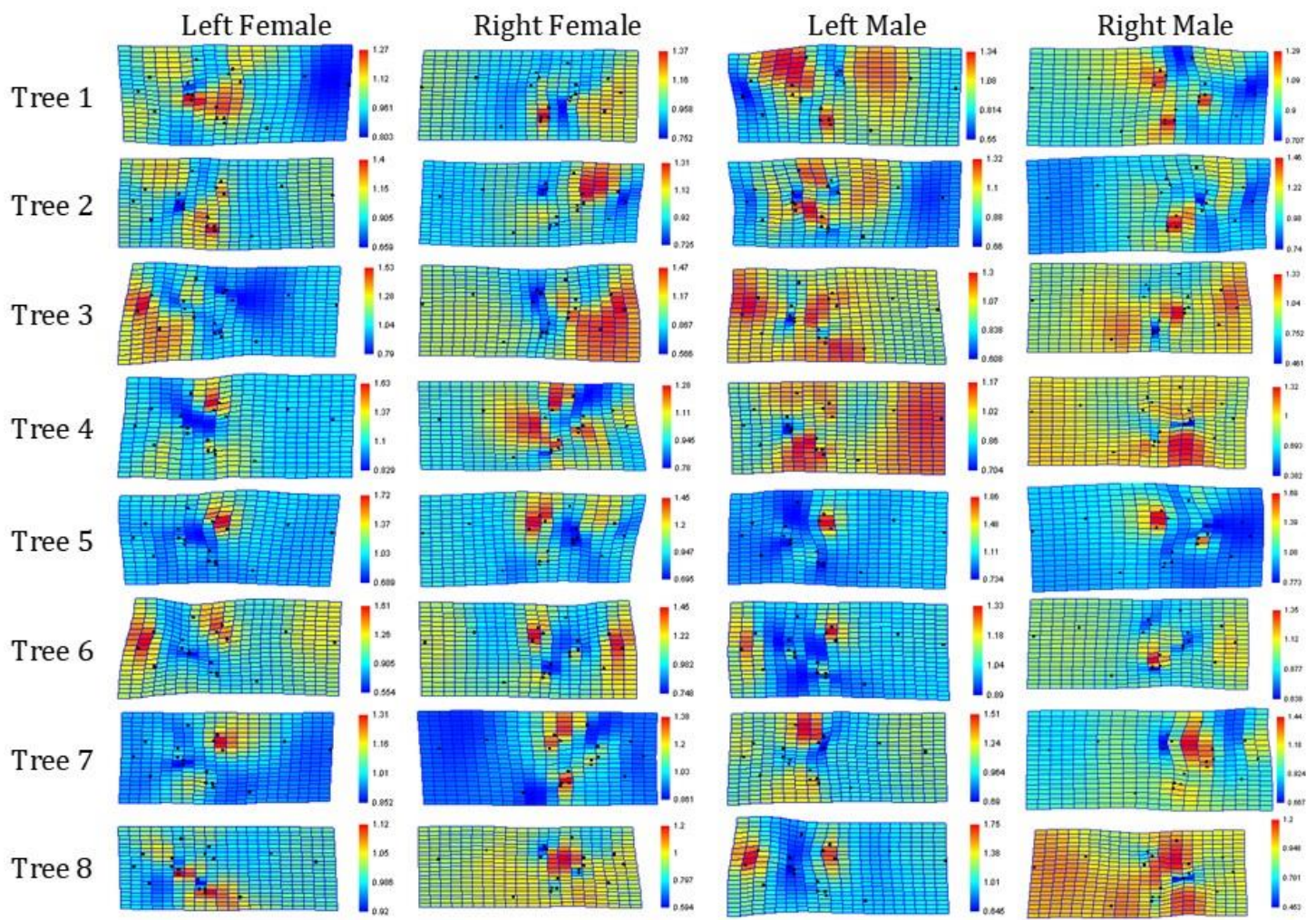

Fig, 4. Thin plate splines of wings between sampled trees in Guimaras Wonders Farm, Guimaras Is.

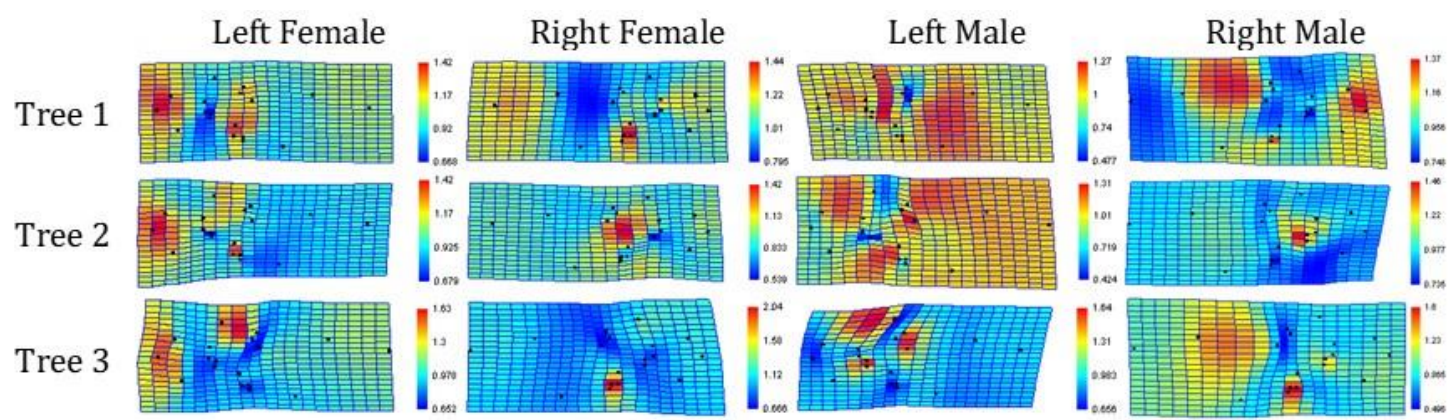

Fig. 5. Thin plate splines of wings between sampled trees in Lacida Farm, Brgy. Buru-un, Iligan city. 


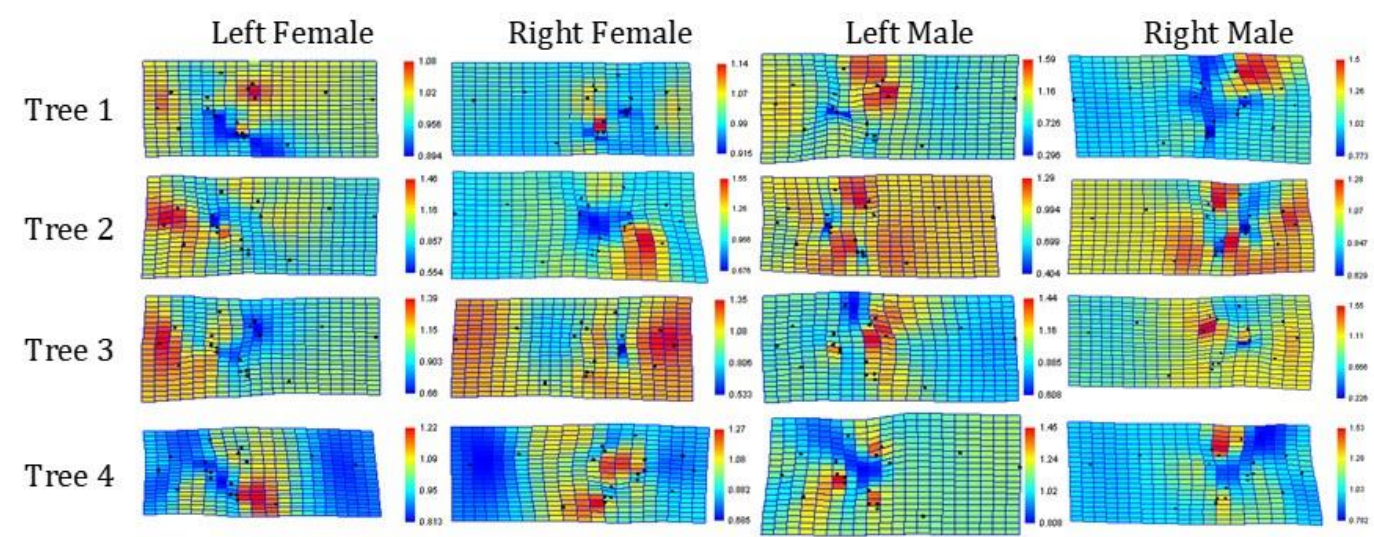

Fig. 6. Thin plate splines of wings between sampled trees in Brgy. McClain, Buenavista, Guimaras.

Relative warp analysis have shown varying degrees of significant warps with the boxplots showing the degree of variation in each tree in an orchard (see Fig. 7). Tree to tree variation in shown to vary. Generally, the first relative warp values are about $60 \%$.
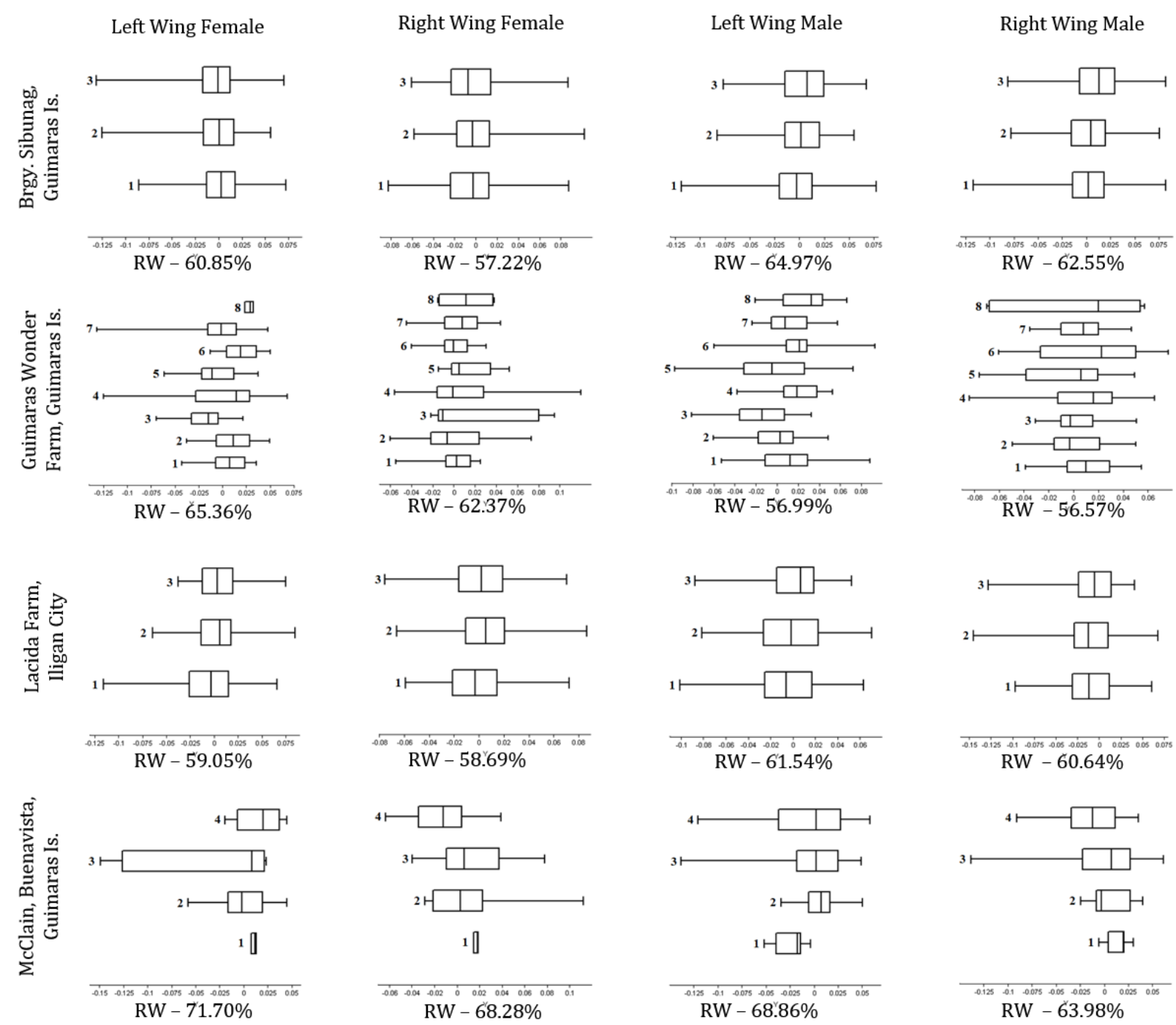

Fig. 7. Relative warp analysis of the forewings of the mango leafhopper, Idioscopus clypealis.

The asymmetry in male and female asymmetry can be symptomatic of sexual dimorphism in the wings of 
the mango leafhopper. The asymmetry in the left and right wings is symptomatic of developmental instability. However the results have shown a pattern of variable adaptability to each. These results have shown that there are significant differences in the wing shapes between trees within an orchard. The individual plant responses influence the phenotypic effect on the mango leafhopper.

The intra-specific defense of the host contributes to the phenotypic changes within the mango leafhopper [16]. However further study is needed to determine what are the variable defenses employed by the plant.

The phenotypic changes particularly on the wing venation can confer differences in wing integrity and flight pattern which can affect reproduction, migration and survival [31].

This study also shows a mosaic of differential genetic expression in each tree leading to phenotypic plasticity of the pest population within an orchard. The control of population using organic or synthetic pesticides may have differential effects on mango leafhopper. Pesticide application may lead to differential rates of survival within an orchard. This is indicative of the persistence of the pest in mango orchards despite control measures instituted over time.

\section{Conclusion}

This study aims to identify the effects of host defense variability and its effect on the mango pest, Idioscopus clypealis. Significant variation was found in the left and right wings of the leafhopper and between sexes across the different hosts in each geographic location. Indicative of sexual dimorphism and developmental instability in the mango leafhopper. However, the phenotypic plasticity observed may be suggestive of insect adaptability to defenses by the host and pesticides of either natural or synthetic origins. Moreover, wing shape variability may affect wing structure, wing flight and sexual selection.

\section{Acknowledgment}

The authors would like to thank the Philippine Department of Science and Technology for the scholarship provided to make this study possible. We also thank the Mindanao State University - Iligan Institute of Technology for providing the space needed to conduct the study. The authors would also like to thank the Bureau of Plant Industry in Guimaras island for the assistance and transportation provided during collection in the island and to Mr. Roger Lacida of Lacida Farms in Brgy. Buruun, Iligan City for the assistance in the collection of samples in his farm.

\section{References}

[1] Howe, G. A., \& Jander, G. (2008). Plant immunity to insect herbivores. Annu. Rev. Plant Biol., 59, 41-66.

[2] Nimchuk, Z., Eulgem, T., Holt Iii, B. F., \& Dangl, J. L. (2003). Recognition and response in the plant immune system. Annual Review of Genetics, 37(1), 579-609.

[3] Nürnberger, T., \& Scheel, D. (2001). Signal transmission in the plant immune response. Trends in Plant Science, 6(8), 372-379.

[4] Walling, L. L. (2000). The myriad plant responses to herbivores. Journal of Plant Growth Regulation, $19(2), 195-216$.

[5] Li, J., Brader, G., \& Palva, E. T. (2004). The WRKY70 transcription factor: A node of convergence for jasmonate-mediated and salicylate-mediated signals in plant defense. The Plant Cell, 16(2), 319-331.

[6] Wu, J., \& Baldwin, I. T. (2009). Herbivory-induced signalling in plants: Perception and action. Plant, Cell \& Environment, 32(9), 1161-1174.

[7] Kessler, A., Halitschke, R., Diezel, C., \& Baldwin, I. T. (2006). Priming of plant defense responses in nature by airborne signaling between Artemisia tridentata and Nicotiana attenuata. Oecologia, 148(2), 280-292. 
[8] Heil, M., \& Karban, R. (2010). Explaining evolution of plant communication by airborne signals. Trends in Ecology \& Evolution, 25(3), 137-144.

[9] Jactel, H., Kleinhentz, M., Marpeau-Bezard, A., Marion-Poll, F., Menassieu, P., \& Burban, C. (1996). Terpene variations in maritime pine constitutive oleoresin related to host tree selection byDioryctria sylvestrella RATZ.(Lepidoptera: Pyralidae). Journal of Chemical Ecology, 22(5), 1037-1050.

[10] Wurst, S., Dam, N. M., Monroy, F., Biere, A., \& Putten, W. H. (2008). Intraspecific variation in plant defense alters effects of root herbivores on leaf chemistry and aboveground herbivore damage. Journal of Chemical Ecology, 34(10), 1360-1367.

[11] Kant, M. R., Sabelis, M. W., Haring, M. A., \& Schuurink, R. C. (2008). Intraspecific variation in a generalist herbivore accounts for differential induction and impact of host plant defences. Proceedings of the Royal Society of London B: Biological Sciences, 275(1633), 443-452.

[12] Zas, R., Moreira, X., Ramos, M., Lima, M. R., da Silva, M. N., Solla, A., Vasconcelos, M. W. \& Sampedro, L. (2015). Intraspecific variation of anatomical and chemical defensive traits in Maritime pine (Pinus pinaster) as factors in susceptibility to the pinewood nematode (Bursaphelenchus xylophilus). Trees, 29(3), 663-673.

[13] Matzke, M. A., Mette, M. F., \& Matzke, A. J. M. (2000). Transgene silencing by the host genome defense: implications for the evolution of epigenetic control mechanisms in plants and vertebrates. Plant Molecular Biology, 43(2-3), 401-415.

[14] Feschotte, C., Jiang, N., \& Wessler, S. R. (2002). Plant transposable elements: Where genetics meets genomics. Nature Reviews Genetics, 3(5), 329-341.

[15] Bennetzen, J. L., Ma, J., \& Devos, K. M. (2005). Mechanisms of recent genome size variation in flowering plants. Annals of botany, 95(1), 127-132.

[16] Thompson, J. N. (2005). The geographic mosaic of coevolution. University of Chicago Press.

[17] Gomulkiewicz, R., Drown, D. M., Dybdahl, M. F., Godsoe, W., Nuismer, S. L., Pepin, K. M., Ridenhour, B. J., Smith, C. I. \& Yoder, J. B. (2007). Dos and don'ts of testing the geographic mosaic theory of coevolution. Heredity, 98(5), 249-258.

[18] Benkman, C. W., Parchman, T. L., Favis, A., \& Siepielski, A. M. (2003). Reciprocal selection causes a coevolutionary arms race between crossbills and lodgepole pine. The American Naturalist, 162(2), 182-194.

[19] Rios, R. S., Salgado-Luarte, C., Stotz, G. C., \& Gianoli, E. (2016). Co-occurrence of host plants associated with plant quality determines performance patterns of the specialist butterfly, Battus polydamas archidamas (Lepidoptera: Papilionidae: Troidini). European Journal of Entomology, 113, 150.

[20] Thompson, J. N., Schwind, C., \& Friberg, M. (2017). Diversification of trait combinations in coevolving plant and insect lineages. The American Naturalist, 190(2), 000-000.

[21] Fletcher, M. J., \& Dangerfield, P. C. (2002). Idioscopus clypealis (Lethierry), a second new leafhopper pest of mango in Australia (Hemiptera: Cicadellidae: Idiocerinae). Austral Entomology, 41(1), 35-38.

[22] Fletcher, M. (1999). Idioscopus clypealis (Lethierry). Industry and Investment NSW Agricultural Scientific Collections Unit.

[23] Rohlf, F. J. (2009). tps Utility program version 1.44. Ecology and Evolution. SUNY, Stony Brook.

[24] Rohlf, F. J. (2008). tpsDig program version 2.12. Ecology and Evolution. SUNY, Stony Brook.

[25] Hammer, Ø., Harper, D. A. T., \& Ryan, P. D. (2001). Paleontological statistics software: Package for education and data analysis. Palaeontologia Electronica, (4).

[26] Dryden, I. L., \& Mardia, K. V. (1998). Statistical Shape Analysis, (4). Chichester: Wiley.

[27] Adams, D. C., Rohlf, F. J., \& Slice, D. E. (2004). Geometric morphometrics: Ten years of progress following the 'revolution'. Italian Journal of Zoology, 71(1), 5-16. 
[28] Bookstein, F. L. (1989). Principal warps: Thin-plate splines and the decomposition of deformations. IEEE Transactions on Pattern Analysis and Machine Intelligence, 11(6), 567-585.

[29] Rohlf, F. J. (1993). Relative warp analysis and an example of its application to mosquito. Contributions to Morphometrics, 8, 131.

[30] Rohlf, F. J. (2008). Relative warps program version 1.46. Ecology and Evolution. SUNY, Stony Brook.

[31] Combes, S. A., \& Daniel, T. L. (2003). Flexural stiffness in insect wings I. Scaling and the influence of wing venation. Journal of Experimental Biology, 206(17), 2979-2987.
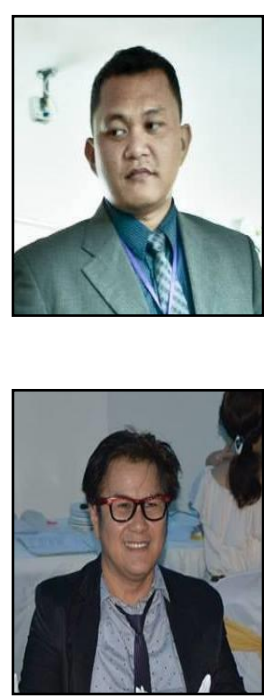

Mark Ronald S. Manseguiao is currently a faculty memberat the Davao del Norte State College. He has a master and Ph.D. degree in biology from the Mindanao State University Iligan Institute of Technology under a scholarship grant with the Philippine Department of Science and Technology - Accelerated Science and Technology Human Resource Development Program. He took up BS Biology from University of the Philippine Mindanao in Davao city.

Cesar G. Demayo is the graduate adviser of the first author. He is a professor in genetics and entomology at the Department of Biological Sciences at the College of Science and Mathematics in Mindanao State University-Iligan Institute of Technology.

His interests focus on a clearer understanding of the keystones of evolutionary biology, that is the principles of variability and natural selection. He believes that the regulation of population numbers of organism would include an investigation of how the genetic structure changes in number, and how genetic factors interact with environmental factors to precipitate with the rise and fall in numbers.

He is experienced and competent in teaching basic and advanced courses in genetics, molecular biology, molecular and biochemical genetics, evolutionary biology, biochemistry and basic natural sciences. 